\title{
STUDY OF ANTIBACTERIAL ACTIVITIES OF THE VOLATILE OIL OF NIGELLA SATIVA LINN ON ANIMAL MODEL
}

\author{
NAZMA ARA ${ }^{1}$,M.A.KHALEQUE ${ }^{2}$ SAR CHOUDHURY ${ }^{3}$ RUHUL AMIN ${ }^{4}$
}

Assistant Professor ${ }^{1}$, Department of Pharmacology,Rajshahi Medical College, Department of Cardiology, Rajshahi Medical College ${ }^{2}$, Former Chairman ${ }^{3}$, Department of Pharmacology, Bangabandhu Sheikh Mujib Medical University, Professor \& Chairman ${ }^{4}$, Department of Microbiology, Bangabandhu Sheikh Mujib Medical University

\begin{abstract}
:
In-vivo antibacterial activity of the volatile oil of Nigella sativa linn was carried out in mice. Mice was infected by inoculation of staph.Aureus and result shows successful iradication of bacterial colony.
\end{abstract}

(Bangladesh J Physiol Pharmacol 2006; 22(1/2) : 22-24)

\section{INTRODUCTION:}

The research of new antimicrobial chemotherapeutic agents occupies attention throughout the world. Generally the test animal for preliminary evaluation is usually the mouse. Here therapy and infection are given by the same route and this procedure is described as "using the mouse as a test tube". ${ }^{1}$ The experiment has been carried out in mice using the method described by Cleeland and Grunberg $^{2}$. Our preview study demonstrated the in-vitro antimicrobial effect. Therefore the present study was designed to investigate the effects of volatile oil of Nigella sativa seeds on iatrogenic staphylococcus infection in mice and this method is referred as testing for local Chemotherapy. ${ }^{3}$

\section{MATERIALS AND METHODS:}

The Niglla sativa linn. seeds were purchased from local market and identified by the Department of Taxonomy, National Herbarium of Bangladesh, Dhaka. The volatile oil was prepared by Clevenger's apparatus on steam distillation and the yield was $0.12 \% \mathrm{w} / \mathrm{v}$. It was dehydrated by passing through anhydrous sodium sulphite and stored in a refrigerator at $4^{\circ} \mathrm{C}$.

Test organism: Pure identified culture of Staph. aureus were collected from the stock cultures from Department of Microbiology, BSMMU. Antimicrobial activity was semiquantitatively determined by using the discagar diffusion techniques. ${ }^{4}$

Collection of Mice: For this study 15 albino mice of 23 months age weighting 30-40 gms were kept at room temperature under condition of natural light and dark

Address of Correspondence: Nazma Ara, Assistant Professor, Department of Pharmacology, Rajshahi Medical College, Rajshahi schedule and fed with good quality basal diet. They were divided into 3 groups.

$1^{\text {st }}$ day: Each mice were given $0.2 \mathrm{ml}$ of an over night culture of Staph. aureus with $01 \mathrm{ml}$ of sterile saline intradermally in the loose skin between the shoulders.

$2^{\text {nd }}$ day: Group 1 (experimental) was treated with $1200 \mu \mathrm{g}$ of volatile oil sample with few drops of glycerin, Group 2 (+ve control) was treated with $1 \mathrm{mg}$ of gentamicin with few drops of glycerin. Group 3 (-ve control) was treated with only a few drops of glycerin.

$3^{\text {rd }}$ day: All mice were sacrificed as per schedule and swab from the site of infection of each mouse was taken and cultured on a nutrient agar plate and incubated at $37^{0} \mathrm{c}$ for $24 \mathrm{hrs}$. Then examined for bacterial growth.

\section{RESULTS:}

Picture of culture plates showing (Fig.-1, Fig.-2 \& Fig. -3) no bacterial growth or the presence of no more than 10 colonies indicated successful treatment of the Staph. aureus. infection. ${ }^{5}$ Experimental (Group 1) group is treated by volatile oil shown apparently no growth or no more than one colony. Group 2 (positive control) which was treated by Gentamicin shows no growth or no more than three colonies. And Group 3 (negative control) which was only treated by glycerin shows heavy bacterial growth, forming a continuous layer ( Shown in the table I,II \& III).

Following tables show the experimental design of the in vivo antibacterial study of the volatile oil in mice model indicating the grouping of animal, average body weight, age and treatment schedule for each group. 
Table-I

\begin{tabular}{|c|c|c|c|c|c|c|}
\hline Gr. 1 & $\begin{array}{l}\text { No. of } \\
\text { mice }\end{array}$ & $\begin{array}{c}\text { Ave. mice } \\
\text { wt(gm) }\end{array}$ & $\begin{array}{c}\text { Mean body } \\
\text { wt(gm) }\end{array}$ & $\begin{array}{c}\text { Ave. age in } \\
\text { month }\end{array}$ & Treatment. & Insference \\
\hline $1 \mathrm{a}$ & & 34 & & $2-3$ & \multirow{5}{*}{$\begin{array}{l}\text { OrganismS.aureus }+1 \mathrm{ml} \\
\text { sterile saline }+10 \mathrm{ml} \text { of } \mathrm{V} \text {. } \\
\text { oil }+\mathrm{few} \text { drops of } \\
\text { glycerine to each mice. }\end{array}$} & \\
\hline $1 \mathrm{~b}$ & & 38 & & $2-3$ & & \\
\hline $1 \mathrm{c}$ & 5 & 38 & 37 & $2-3$ & & NG. \\
\hline $1 \mathrm{~d}$ & & 35 & & $2-3$ & & \\
\hline $1 \mathrm{e}$ & & 40 & & $2-3$ & & \\
\hline
\end{tabular}

Group-1 is Experimental i.e. treated by N. sativa volatile oil.

$N G=$ No Growth.

Table-II

\begin{tabular}{|c|c|c|c|c|c|c|}
\hline Gr. 2 & $\begin{array}{l}\text { No. of } \\
\text { mice }\end{array}$ & $\begin{array}{l}\text { Ave. wt. of } \\
\text { mice (gm) }\end{array}$ & $\begin{array}{c}\text { Meanwt. } \\
\text { in (gm) }\end{array}$ & $\begin{array}{c}\text { Ave. age in } \\
\text { mount hs. }\end{array}$ & Treatment. & Insference \\
\hline $2 a$ & \multirow{5}{*}{5} & 32 & \multirow{5}{*}{35} & $2-3$ & \multirow{5}{*}{$\begin{array}{l}\text { Organism S.aureus }+1 \mathrm{ml} \\
\text { sterile saline }+1 \mathrm{mg} \\
\text { gentamicin }+ \text { few drops of } \\
\text { glycerine }\end{array}$} & \multirow{5}{*}{ NG. } \\
\hline $2 b$ & & 38 & & $2-3$ & & \\
\hline $2 c$ & & 38 & & $2-3$ & & \\
\hline $2 d$ & & 35 & & $2-3$ & & \\
\hline $2 e$ & & 40 & & $2-3$ & & \\
\hline
\end{tabular}

Group-2 is Positive control i.e. treated by gentamicin. $\mathrm{NG}=$ No Growth.

Table-III

\begin{tabular}{|c|c|c|c|c|c|c|}
\hline Gr. 3 & $\begin{array}{l}\text { No. of } \\
\text { mice }\end{array}$ & $\begin{array}{l}\text { Ave. wt. of } \\
\text { mice (gm) }\end{array}$ & $\begin{array}{l}\text { Mean wt. } \\
\text { in (gm) }\end{array}$ & $\begin{array}{l}\text { Ave. age in } \\
\text { mount hs. }\end{array}$ & Treatment. & Insference \\
\hline $3 a$ & \multirow{5}{*}{5} & 32 & \multirow{5}{*}{34} & $2-3$ & \multirow{5}{*}{$\begin{array}{l}\text { Organism S. } \\
\text { aureus }+1 \mathrm{ml} \\
\text { sterile saline+ } \\
\text { few drops of } \\
\text { glycerine. }\end{array}$} & \multirow{5}{*}{$\begin{array}{l}\text { Heavy } \\
\text { growth in } \\
\text { all plates }\end{array}$} \\
\hline $3 b$ & & 34 & & $2-3$ & & \\
\hline $3 c$ & & 36 & & $2-3$ & & \\
\hline $3 d$ & & 36 & & $2-3$ & & \\
\hline $3 e$ & & 32 & & $2-3$ & & \\
\hline
\end{tabular}

Group-3 is Negative control i.e. treated by glycerin. Heavy bacterial growth

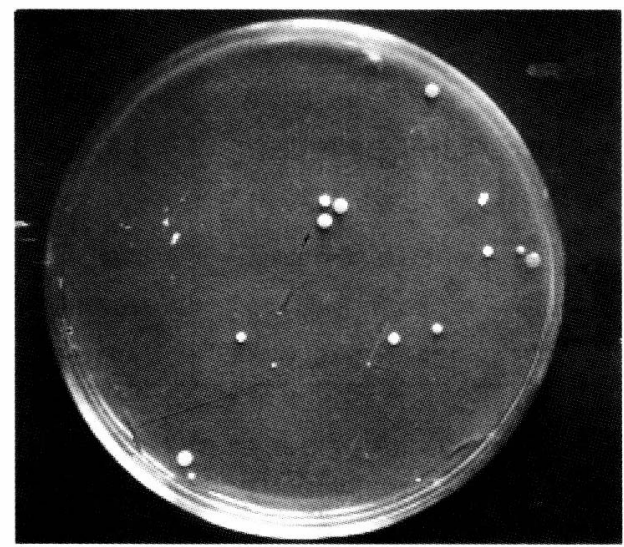

Fig.-1: (Experimental) treated by N. Sativa volatile oil showing no growth.

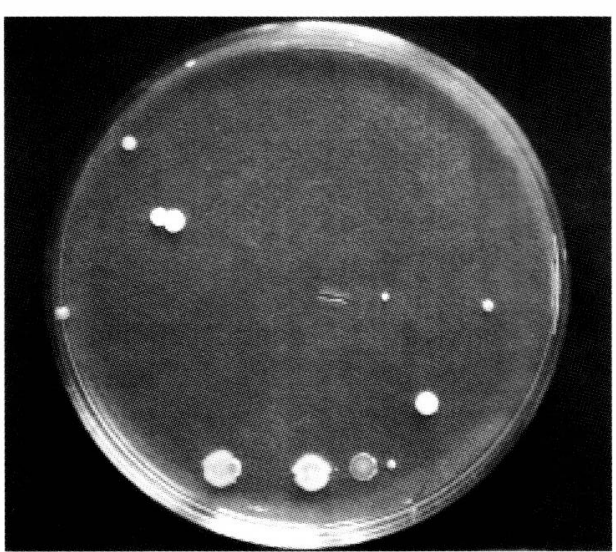

Fig.-2: Positive control i.e. treated by gentamicin showing no growth. 


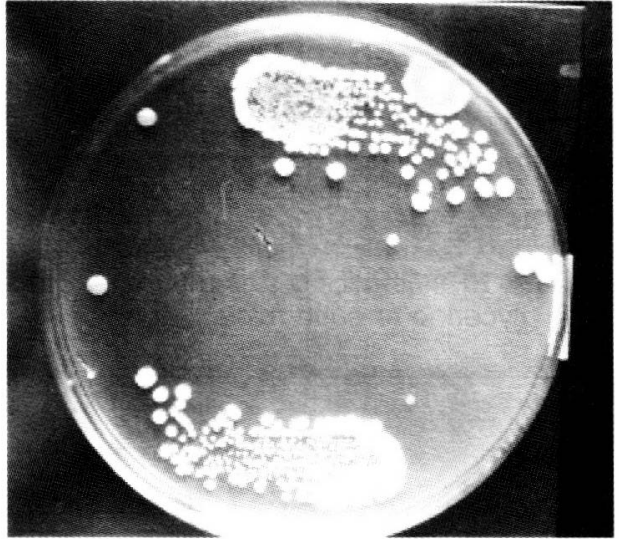

Fig.-3: Negative control i.e. treated by glycerin showing heavy bacterial growth

\section{DISCUSSION:}

Results of in vivo studies shows that the volatile oil of Nigella sativa linn seed successfully eradicate local infection of Staphylococcous aureus in mice and this eradication of growth of organisms is equivalent to that of a standard antibiotic Gentamicin. A previous study of Nigella sativa extract showed antibacterial synergism with streptmycin and gentamicin. ${ }^{6}$ Thus Niglla sativa seeds can possibly provide the basis for a successful antibacterial preparation for the chemotherapy of localized infection. From this study it seems that the Volatile oil can be incorporated in topical formulations.

\section{REFERENCES:}

1. Browning $\mathrm{CH}$. In: Experimental Chemotherapy. Schnitzer RJ, Hawking F, eds. New York: Academic press, 1964: Vol .2, pp.1-36.

2. Miller A.K. Advances in Applied Microbiology. Perlman D, ed. New York, Sanfransisco, London: Academic press, 1971; $14: 152-159$

3. Cleeland.R, Grunbreg E. Laboratory Evalution of new antibiotics in vitro and experimental animal infection. In: Antibiotics in Laboratory Medicine, Lorian V, ed . Baltimare: Williams and Williams, 1979 pp. 506-547

4. Namba T, Tsunezuka M, Dissnayake DMRB. Pilapitya US, Kakiuche NK, Hattori M. Studies on dental carries prevention by traditional medicines for anti-plaque action. Jap J Pharmacognosy 1985;39:146-153

5. Finegold SM, Martin HJ. Diagnostic Microbiology $6^{\text {th }}$ Edition. C.I London: Mozloy Company, 1982 pp. 532-557.

6. Hanafy MS, Hatem ME. Studies of antibacterial activity of Nigella sativa (black cumin). JEthnopharmacology 1991;34:275-278. 